\title{
Littoral hydrovolcanic explosions: a case study of lava-seawater interaction at Kilauea Volcano
}

\author{
Tari N. Mattox ${ }^{*}$, Margaret T. Mangan ${ }^{1}$ \\ Hawaiian Volcano Observatory, U.S. Geological Survey, P.O. Box 51, Hawai‘i National Park, HI 96718, USA
}

Received 1 October 1995; accepted 6 June 1996

\begin{abstract}
A variety of hydrovolcanic explosions may occur as basaltic lava flows into the ocean. Observations and measurements were made during a two-year span of unusually explosive littoral activity as tube-fed pahoehoe from Kilauea Volcano inundated the southeast coastline of the island of Hawai ${ }^{i} i$. Our observations suggest that explosive interactions require high entrance fluxes $\left(\geq 4 \mathrm{~m}^{3} / \mathrm{s}\right)$ and are most often initiated by collapse of a developing lava delta. Two types of interactions were observed. "Open mixing" of lava and seawater occurred when delta collapse exposed the mouth of a severed lava tube or incandescent fault scarp to wave action. The ensuing explosions produced unconsolidated deposits of glassy lava fragments or lithic debris. Interactions under "confined mixing" conditions occurred when a lava tube situated at or below sea level fractured. Explosions ruptured the roof of the tube and produced circular mounds of welded spatter. We estimate a water/rock mass ratio of 0.15 for the most common type of littoral explosion and a kinetic energy release of $0.07-1.3$ $\mathrm{kJ} / \mathrm{kg}$ for the range of events witnessed.
\end{abstract}

Keywords: littoral cone; explosion phenomenon; lava; pahoehoe; pyroclasts; Kilauea; basalt

\section{Introduction}

Kilauea Volcano has been in near-continuous eruption since 1983. For nearly eight years, flows from this eruption have entered the ocean on the accessible south flank of the volcano, providing an excellent opportunity to study, at close hand, the interaction between molten lava and water (e.g., Tribble, 1991; Sansone et al., 1991). Pahoehoe flows

\footnotetext{
* Corresponding author. Present address: CSIRO, Division of Exploration and Mining, Private Bag, PO Wembley, W.A. 6014, Australia. Tel.: +61-9-387-0786; fax: +61-9-383-7993; e-mail: t.mattox@per.dem.csiro.au.

${ }^{1}$ Fax + 808-967-8890; e-mail mmangan@ tako.wr.usgs.gov.
}

advance down the flank of the volcano from active vents on the rift zone and form a system of tubes that transport lava to the coastline with minimal cooling. An average volume of $350,000 \mathrm{~m}^{3} /$ day of lava was fed through the tube system between 1986 and 1994 (J. Kauahikaua, USGS, unpublished geophysical data). During this time, $2 \mathrm{~km}^{2}$ of new land was added to the island (Fig. 1).

In this paper we specifically characterize a period between 1992 and 1994. During these two years, lava flows entering the ocean in the Kamoamoa area of Hawai'i Volcanoes National Park built a delta 2.9 $\mathrm{km}$ long and $500 \mathrm{~m}$ wide. The evolution of the delta was distinguished by unprecedented hydrovolcanic activity (Table 1). We describe the various types of 


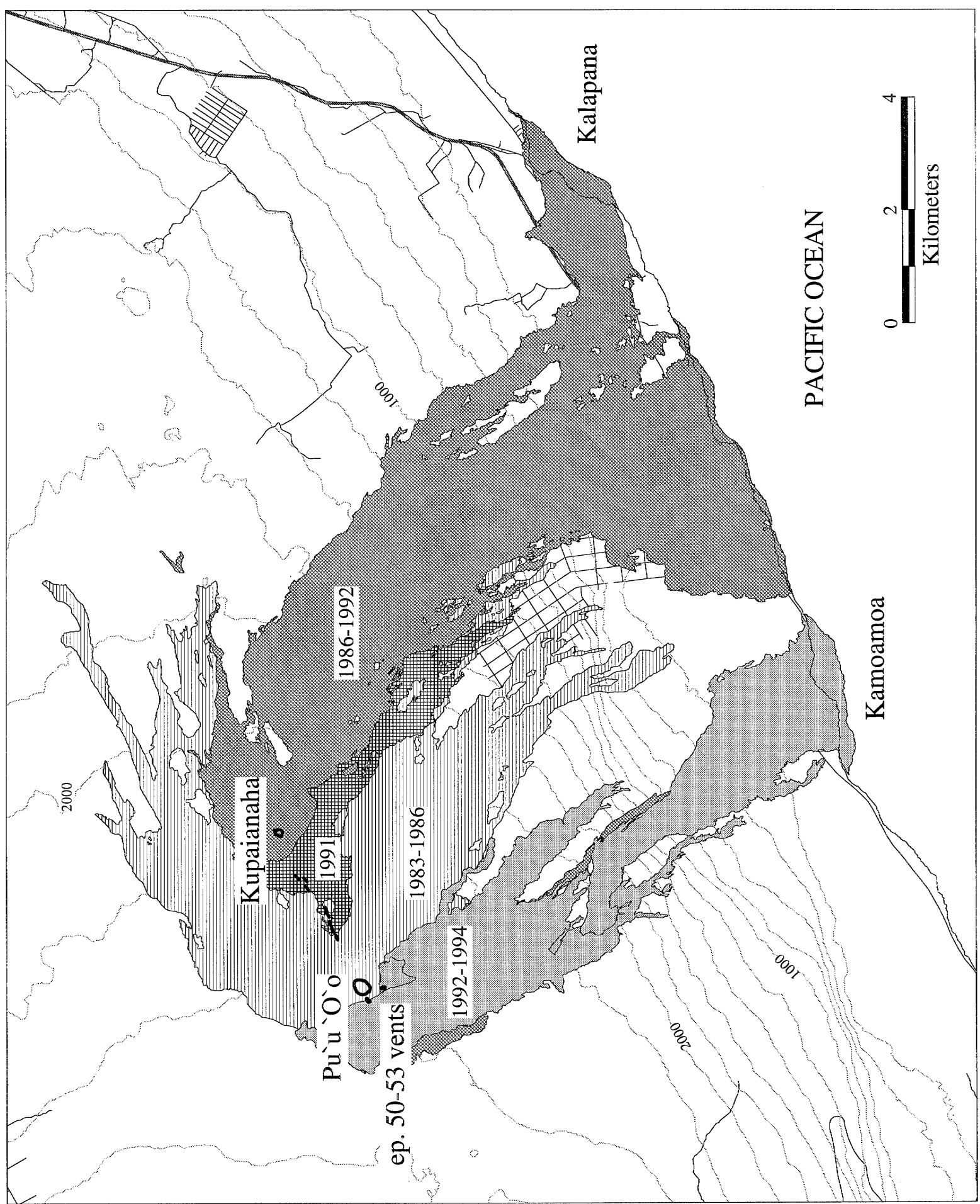



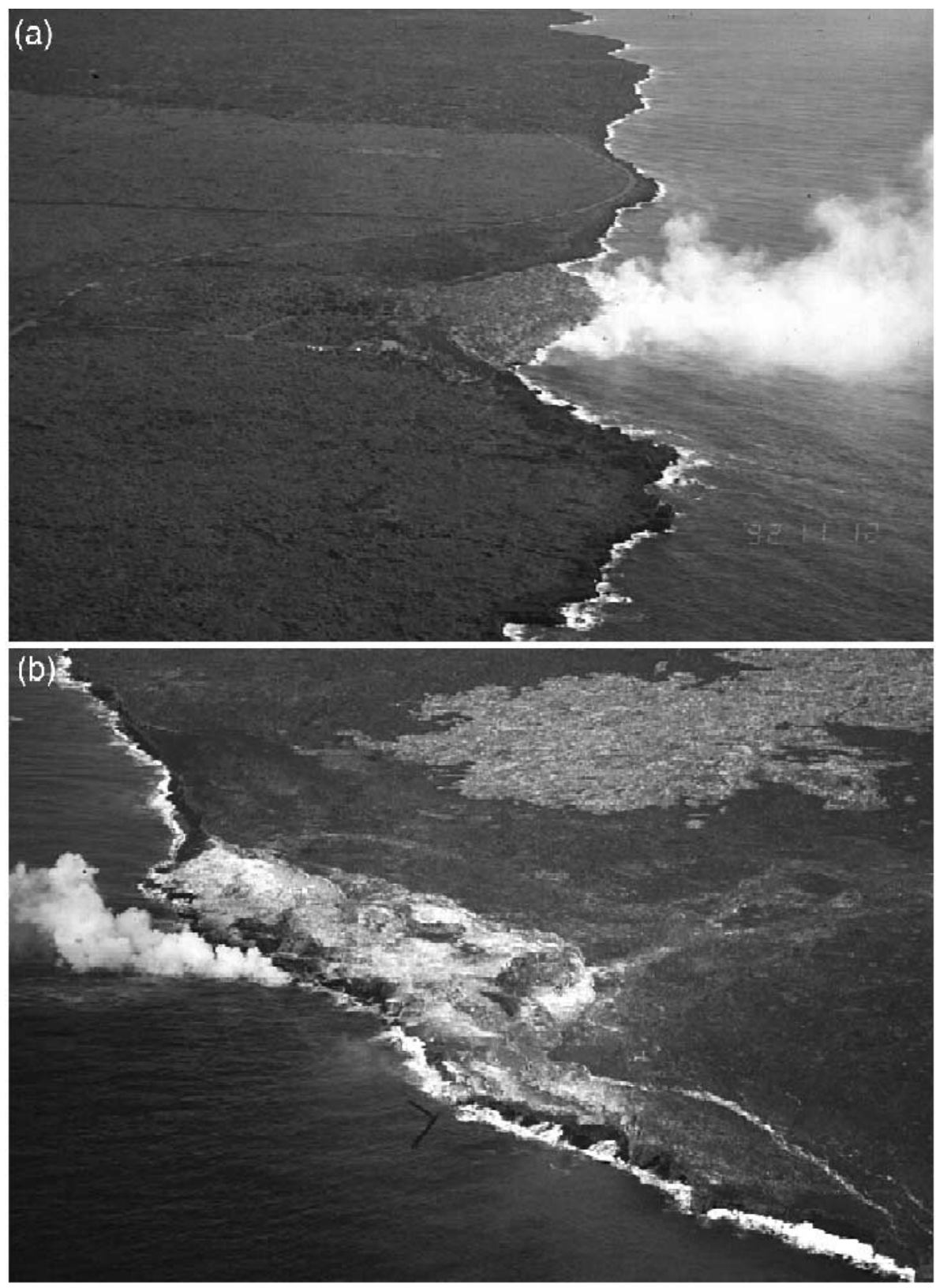

Fig. 2. (a) Aerial view of a prograding lava delta. Note the diffuse plume of white steam at the leading edge of the delta, indicative of multiple small streams pouring into the ocean. The delta is approximately $500 \mathrm{~m}$ wide and extends about $200 \mathrm{~m}$ into the ocean in this image. (b) Aerial view of a mature lava delta. The delta has begun to collapse into the ocean, forming a lava bench that is separated from the main delta by an ocean-facing scarp. Note the consolidated steam plume, evidence of focused entry of lava into the ocean. The bench is approximately $350 \mathrm{~m}$ wide and extends about $60 \mathrm{~m}$ into the ocean in this image.

Fig. 1. Map of lava flows from Kilauea's East Rift Zone eruption. This map shows the dates and distribution of flows from the major vents erupted between 1983 and 1994. Most of the material erupted since 1986 has entered the ocean along a 12-km-long stretch of the southeast coast of Hawai' $i$. The former coastline is shown for reference. The contour interval is 200 feet. 
event observed, and identify some of the physical factors constraining the style and intensity of explosions. Conditions required to initiate littoral explosions on pahoehoe flows are compared in a general way with hydrovolcanic activity associated with advancing ' $a$ 'a flows.

\section{Littoral setting}

When pahoehoe flows first reach the ocean, the interaction is relatively quiescent. Flow lobes drip over old sea cliffs or spread out along established beaches. The lava is passively quenched as it enters the surf zone and shatters to glassy blocks and lapilli. These fragments build a loose submarine debris slope. Later flows build out on this slope to form lava deltas (Figs. 1 and 2a,b), which eventually can extend hundreds of meters seaward (Moore et al., 1973; Mattox, 1993a,b). As the flow field matures, a tube system is established within the delta, and lava enters the ocean at a few discrete points. Typical volume fluxes of $2-5 \mathrm{~m}^{3} / \mathrm{s}$ flow through tubes $1-3$ $\mathrm{m}$ in diameter (Jackson et al., 1988; Heliker et al., 1993; Kauahikaua et al., 1996; J. Kauahikaua, USGS, unpublished geophysical data). Tubes at the leading edge of the delta often reside at, or below, sea level (J. Kauahikaua, USGS, unpublished geophysical data).

The rate of delta formation depends largely on submarine bathymetry and the volume flux of lava entering the ocean (Hon et al., 1993). The two largest deltas built during this eruption filled small bays at Kalapana and Kamoamoa (Fig. 1). During the first few days of construction, these deltas grew at rates of $\sim 38,500$ and $\sim 18,500 \mathrm{~m}^{2} /$ day, respectively (Fig. 3). Both continued to advance in the following weeks, but at reduced rates as the leading edge of the delta moved beyond the shallow waters of the coastline and encountered steep offshore slopes. The developing tube system "caught up" with the active delta front as growth slowed, and the lava streams flowing into the ocean consolidated into a single, well-defined tube entry. It is at this time that the leading edge of the delta becomes prone to catastrophic collapse. Geodetic monitoring of active lava deltas has revealed subsidence rates of several centimeters per month (Kauahikaua et al., 1993). Subsidence of the delta is coincident with inflation of lava tubes (Kauahikaua et al., 1993) and the development of large cracks parallel to the coast.

The unstable front of the delta, or lava bench, is bounded inland by an ocean-facing scarp (Fig. 2b and Fig. 4A). This scarp can be either a pre-existing sea cliff or a new failure surface. Lava benches on the Kamoamoa delta were separated from the main delta by a 1 - to 10 -m-high scarp. The benches were typically elliptical and extended up to $\sim 200 \mathrm{~m}$ along the coastline and $\sim 40 \mathrm{~m}$ seaward. They collapsed repeatedly during the evolution of the delta.

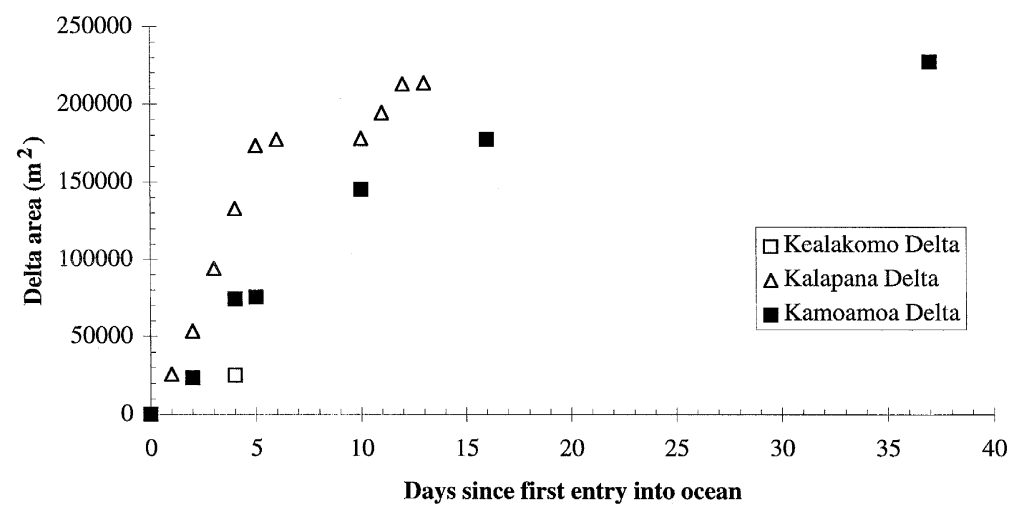

Fig. 3. Growth rates for the Kamoamoa and Kalapana deltas, with Kealakomo delta (Mauna Ulu, Moore et al., 1973) for comparison. Lava flows entering the ocean during the Mauna Ulu eruption of Kilauea built a delta at a rate of 6000-9000 $\mathrm{m}^{2} /$ day (Moore et al., 1973). The lower rate of growth is a reflection of steeper off-shore bathymetry. Both the Kamoamoa and Kalapana lava deltas were formed in shallow bays; their growth rates declined once the flows reached steeper submarine slopes. 


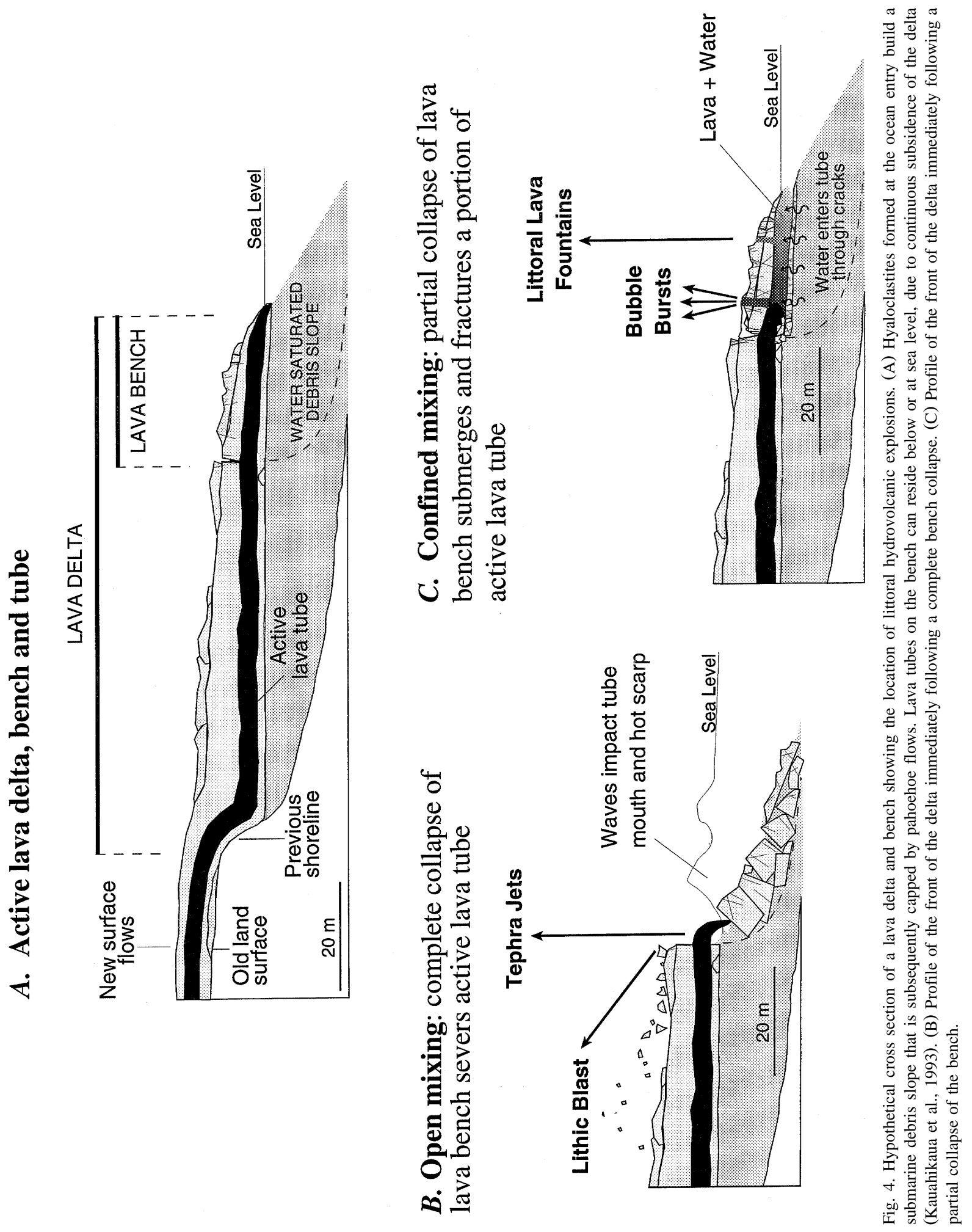


During most collapses, the bench slumped into the ocean, severing the lava tube. Occasionally, the bench subsided abruptly but did not break away. In these instances, the lava tube fractured but remained essentially intact. Almost all collapses led to explosive mixing of seawater and lava.

\section{Types of explosions}

We have identified four general types of hydrovolcanic explosion that occur in the setting described above: tephra jets, lithic blasts, bubble bursts and littoral lava fountains. The actual explosive events, listed in Table 1, tend to be combinations of these four end-members.

\subsection{Tephra jets}

Tephra jets are the most common form of littoral hydroexplosion (Fig. 4B and Fig. 5). This type of event occurs when a bench collapse severs an active lava tube and an open stream of lava is subjected to intense wave action. Waves impacting this stream of lava "explode"' in a cloud of steam and black tephra that attains heights $\leq 40 \mathrm{~m}$. Jets are highest immediately following the collapse and diminish with time. Timed trajectories of tephra in the jets indicate ejection velocities of $1-15 \mathrm{~m} / \mathrm{s}$. (These must be considered minimum values, as we have no observations of the most violent period that immediately follows the collapse.) Explosions occur sporadically over periods from hours to days, until the tube is re-established and seals over. In the absence of a bench collapse, similar, albeit smaller, explosions occur when the crust over a littoral tube sloughs off and the molten lava within is exposed to the surf.

Most of the ejected clasts are angular, wellquenched glass. Approximately $80 \%$ of the clasts (by mass) are less than $5 \mathrm{~mm}$ in diameter. Tephra jets also produce spatter bombs, lapilli and coarse ash. Ash particles typically consist of delicate Pele's hair and flakes of basaltic glass (limu-o-Pele; see Hon et al., 1988). Most ash particles undergo post-explosive mechanical fragmentation and exhibit both fluidal and fractured surfaces (Fig. 6a and b). The spatter fragments have vesicularities between $\sim 10$ and $20 \%$ (Cashman and Mangan, 1994).

Prolonged or vigorous activity in a single location can lead to the formation of unconsolidated to par-

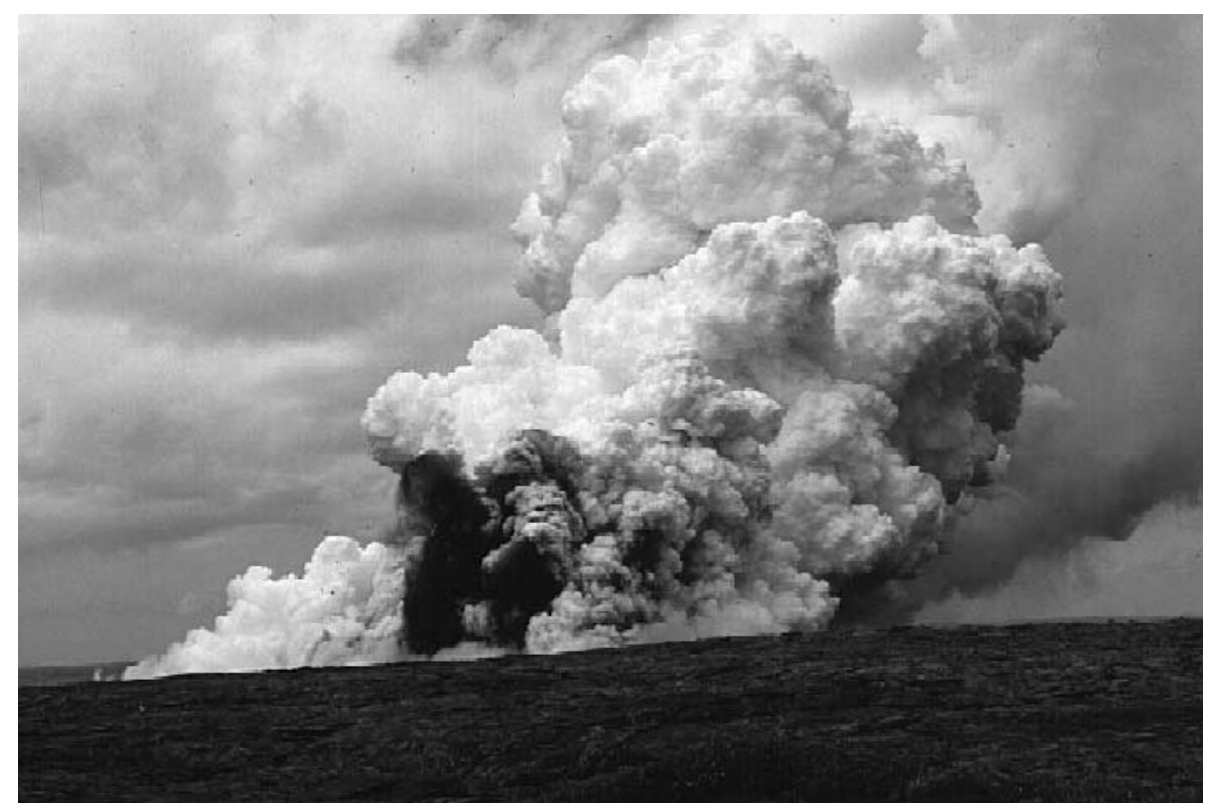

Fig. 5. High-energy tephra jet. Violent interaction between the ocean and an exposed tube, immediately following a bench collapse. Jets of quenched lava fragments and spatter can reach more than $40 \mathrm{~m}$ in height. 
Table 1

List of major explosive events on the Kamoamoa delta

\begin{tabular}{|c|c|c|c|c|}
\hline $\begin{array}{l}\text { Date } \\
(\sim \text { duration })\end{array}$ & $\begin{array}{l}\text { Trigger (area } \\
\text { of collapse) }\end{array}$ & Explosion type & $\begin{array}{l}\text { Maximum height } \\
\text { of ejecta }\end{array}$ & Landforms/deposits \\
\hline $\begin{array}{l}11 / 24 / 92 \\
10.5 \mathrm{~h}\end{array}$ & partial bench collapse & $\begin{array}{l}\text { bubble bursts } \\
\text { littoral lava fountains } \\
\text { steam jets }\end{array}$ & $\geq 100 \mathrm{~m}$ & $\begin{array}{l}\text { Spatter-dominated, circular littoral cone, } \\
7.5 \mathrm{~m} \text { high; field of spatter and blocks. }\end{array}$ \\
\hline $\begin{array}{l}04 / 19 / 93 \\
1 \mathrm{~min}\end{array}$ & bench collapse & lithic blast & not known & $\begin{array}{l}\text { Field of } 0.25-1.1 \mathrm{~m} \text { blocks extending } \\
200 \mathrm{~m} \text { inland. }\end{array}$ \\
\hline $05 / 17 / 93$ & bench collapse & lithic blasts * & not known & Field of blocks extending $100 \mathrm{~m}$ inland. \\
\hline $\begin{array}{l}05 / 28 / 93 \\
>1.5 \mathrm{~h}\end{array}$ & bench collapse & tephra jets & $\geq 40 \mathrm{~m}$ & Unconsolidated, semi-circular littoral cone. \\
\hline $7 / 3 / 93$ & bench collapse & tephra jets * & not known & Unconsolidated, semi-circular littoral cone. \\
\hline $\begin{array}{l}8 / 23 / 93 \\
2 \mathrm{~h}\end{array}$ & $\begin{array}{l}\text { partial bench collapse } \\
\left(8000 \mathrm{~m}^{2}\right)\end{array}$ & $\begin{array}{l}\text { bubble bursts } \\
\text { littoral lava fountains }\end{array}$ & $\geq 100$ & $\begin{array}{l}\text { Low-profile spatter-dominated, circular } \\
\text { littoral cone; field of spatter and blocks } \\
\text { extending } 30 \mathrm{~m} \text { inland. }\end{array}$ \\
\hline $11 / 26 / 93$ & $\begin{array}{l}\text { bench collapse } \\
\left(20,000 \mathrm{~m}^{2}\right)\end{array}$ & tephra jets * & not known & Small field of spatter. \\
\hline $02 / 01 / 94$ & $\begin{array}{l}\text { bench collapse } \\
\left(5000 \mathrm{~m}^{2}\right)\end{array}$ & tephra jets * & not known & Unconsolidated, semi-circular littoral cones. \\
\hline $02 / 08 / 94$ & $\begin{array}{l}\text { bench collapse } \\
\left(4000 \mathrm{~m}^{2}\right)\end{array}$ & tephra jets * & not known & Unconsolidated, semi-circular littoral cones. \\
\hline $\begin{array}{l}02 / 22 / 94 \\
>1 \mathrm{~h}\end{array}$ & $\begin{array}{l}\text { bench collapse } \\
\left(10,000 \mathrm{~m}^{2}\right)\end{array}$ & tephra jets & $>30 \mathrm{~m}$ & $\begin{array}{l}\text { Unconsolidated, semi-circular littoral cone; } \\
\text { field of spatter extending } 80 \mathrm{~m} \text { inland. }\end{array}$ \\
\hline $03 / 01 / 94$ & not known & bubble bursts & $15-25 \mathrm{~m}$ & Spatter-dominated semi-circular littoral cone. \\
\hline $\begin{array}{l}03 / 02 / 94 \\
>45 \min \end{array}$ & bench collapse & bubble bursts & $\geq 100 \mathrm{~m}$ & $\begin{array}{l}\text { Spatter-dominated semi-circular littoral cone } \\
\text { (continuation of above); field of spatter } \\
(\leq 0.7 \mathrm{~m}) \text { and blocks }(\leq 0.3 \mathrm{~m}) \\
\text { extending } 35 \mathrm{~m} \text { inland. }\end{array}$ \\
\hline $\begin{array}{l}03 / 03 / 94- \\
03 / 05 / 94 \\
>30 \mathrm{~h}\end{array}$ & bench collapse & $\begin{array}{l}\text { bubble bursts } \\
\text { tephra jets } \\
\text { littoral lava fountains }\end{array}$ & $\geq 100 \mathrm{~m}$ & $\begin{array}{l}\text { Spatter-dominated littoral cone } \\
\text { (same as above), } \\
6 \mathrm{~m} \text { high; field of blocks. }\end{array}$ \\
\hline $\begin{array}{l}03 / 08 / 94- \\
03 / 10 / 94 \\
43 \mathrm{~h}\end{array}$ & not known & bubble bursts & $>30 \mathrm{~m}$ & $\begin{array}{l}\text { Spatter-dominated, circular littoral cone } \\
\text { ( } 8 \mathrm{~m} \text { high, } 28 \mathrm{~m} \text { wide) and mounds; } \\
\text { field of spatter }\end{array}$ \\
\hline $07 / 08 / 94$ & $\begin{array}{l}\text { bench collapse } \\
\left(4000 \mathrm{~m}^{2}\right)\end{array}$ & tephra jets * & not known & $\begin{array}{l}\text { Unconsolidated, semi-circular littoral cones; } \\
\text { field of spatter and tsunami-deposited blocks. }\end{array}$ \\
\hline $\begin{array}{l}07 / 27 / 94 \\
12.5 \mathrm{~h}\end{array}$ & partial bench collapse & $\begin{array}{l}\text { tephra jets } \\
\text { bubble bursts }\end{array}$ & $\geq 40 \mathrm{~m}$ & $\begin{array}{l}\text { Spatter-dominated to unconsolidated, } \\
\text { semi-circular littoral cone, } \sim 7 \mathrm{~m} \text { high; } \\
\text { field of spatter and lava fragments }\end{array}$ \\
\hline
\end{tabular}

Some events were not directly observed and evidence for them was discovered after-the-fact. These are marked by an asterisk ( $\left.{ }^{*}\right)$ after the presumed explosion type. 
tially agglutinated semicircular littoral cones up to 8 $\mathrm{m}$ high on the seaward margin of the delta or bench (Fig. 7). Cones can build slowly, over the course of several weeks, or more rapidly; deposition rates of 8 $\mathrm{m}$ over 24 hours have been observed. Blankets of lapilli and ash are also deposited on the delta by prolonged explosive activity. These deposits of Pele's hair and limu-o-Pele can be several centimeters thick near the source of the explosions and thin downwind.

\subsection{Lithic blasts}

Collapse of a lava bench can initiate a violent ejection of hot rock, or lithic blast. Ocean water
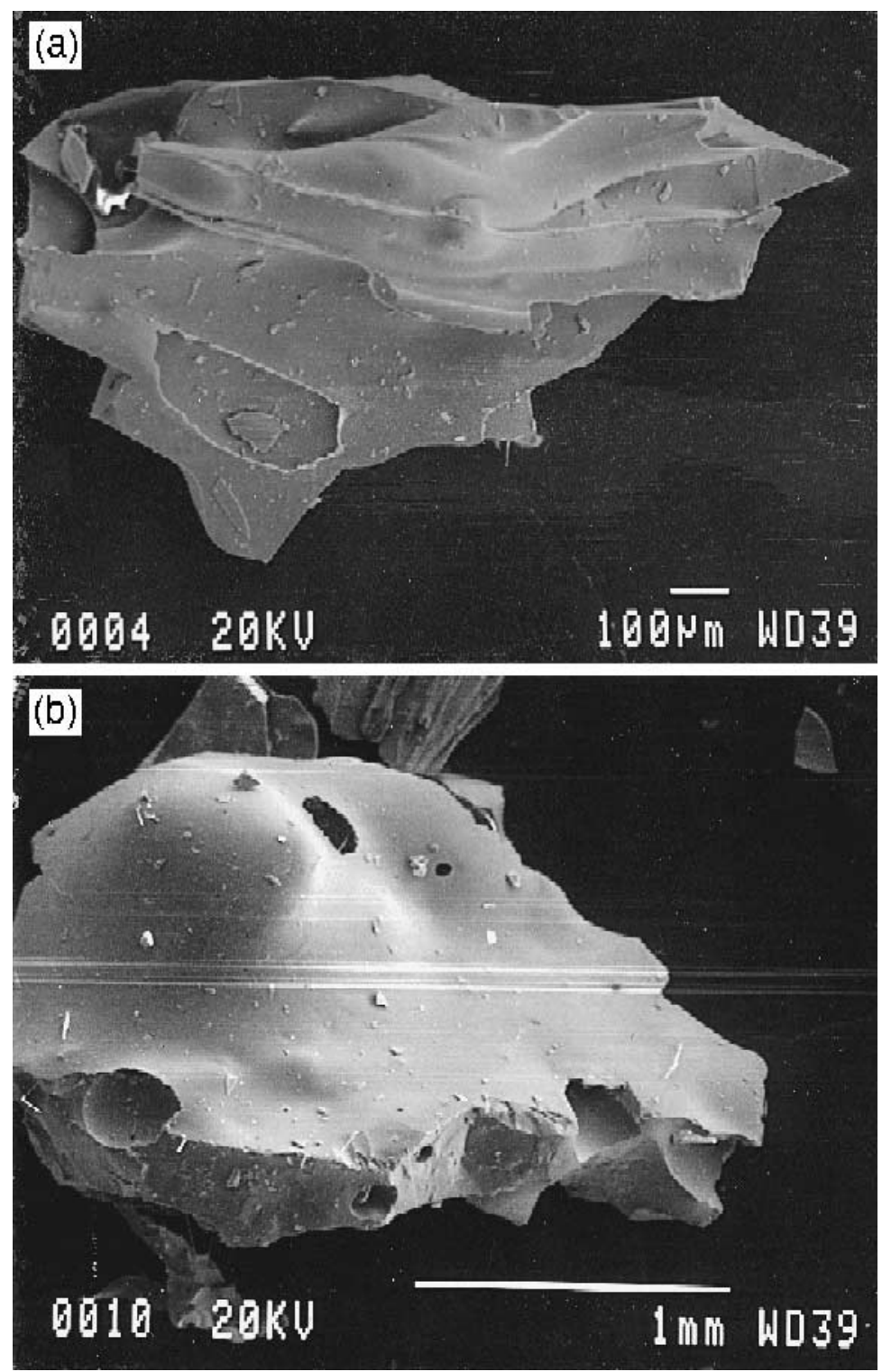

Fig. 6. SEM images of ash produced in tephra jets. (a) Ash formed in tephra jets is dominantly delicate fluidal tephra with fractured surfaces. (b) This glass fragment has the low vesicularity typical of littoral ash. 
comes into contact with the newly exposed incandescent rock scarp and generates a steam explosion that rips up previously emplaced flows and deposits lapilli to block-sized fragments up to $200 \mathrm{~m}$ inland (Fig. 4B). These blasts are singular events but often precede other types of explosive activity (e.g., tephra jets). Most often the blast is directed and, as a result, the deposits are generally not symmetric around the excavation point. They may or may not overlap with deposits resulting from subsequent explosions associated with the collapse. The bench collapse on April 19, 1993 (Table 1) took the life of one National Park visitor, and the resulting lithic blast showered 0.251.1- $\mathrm{m}$ blocks over a $15,000-\mathrm{m}^{2}$ area inland from the sea cliff, injuring several others.

Lithic blast deposits are readily distinguishable from blocks deposited by the localized "tsunami" that are sometimes generated when seawater displaced by a collapsing bench rushes onto the delta. These deposits can extend up to $40 \mathrm{~m}$ inland and 10-15 $\mathrm{m}$ above sea level and leave no impact marks on the underlying flow. The underlying flows are often crusted with salt and scoured of their friable, glassy rinds, which have been washed into cracks and depressions in the flow field.

\subsection{Lava bubble bursts}

Lava bubble bursts are a relatively mild form of a hydrovolcanic explosion that occurs when a lava tube at, or below, sea level fractures abruptly, allowing seawater to enter the tube system very rapidly. This type of activity is characterized by sporadic bursts of molten, dome-shaped lava sheets emanating from a circular rupture in the roof of a tube a few meters inland from the shoreline (Fig. 4C and Fig. 8). Bubbles can reach diameters of $10 \mathrm{~m}$ in less than 2 seconds before bursting. The bubble fragments continue on their radial trajectories for up to $10 \mathrm{~m}$ before falling to the ground. At the end of the explosive sequence, a pool of lava remains that gradually drains away. The bursts are frequently accompanied by a loud boom that shakes the entire delta.

Bubble bursts eject molten lapilli to bomb-sized clasts (ribbon and cow-pie spatter) and lesser amounts of broken limu-o-Pele and Pele's hair. Generally, the surfaces of spatter bombs and lapilli are smooth, glassy and unaltered. A few of the larger bombs continue to expand after deposition to produce bread-crusted surface textures. Repeated bursts form

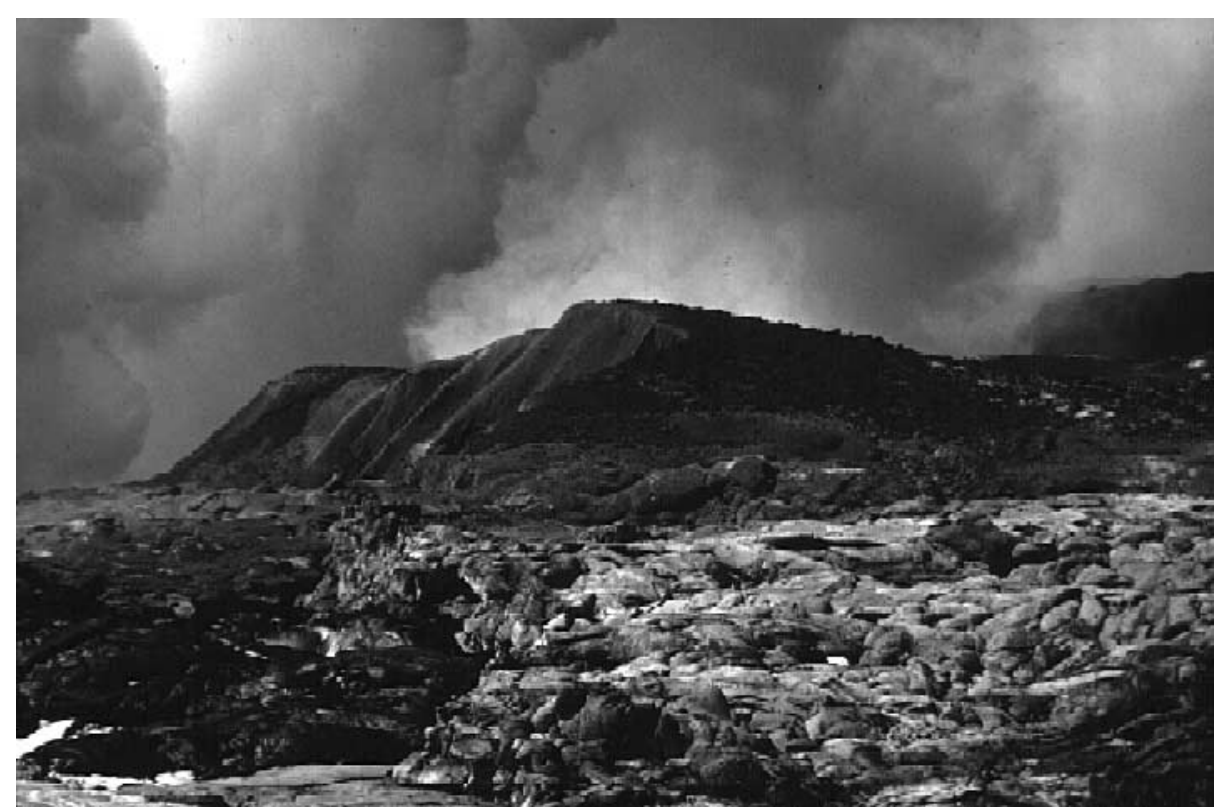

Fig. 7. Littoral cones formed by tephra jets. Explosive activity following a bench collapse formed these unconsolidated littoral cones. 


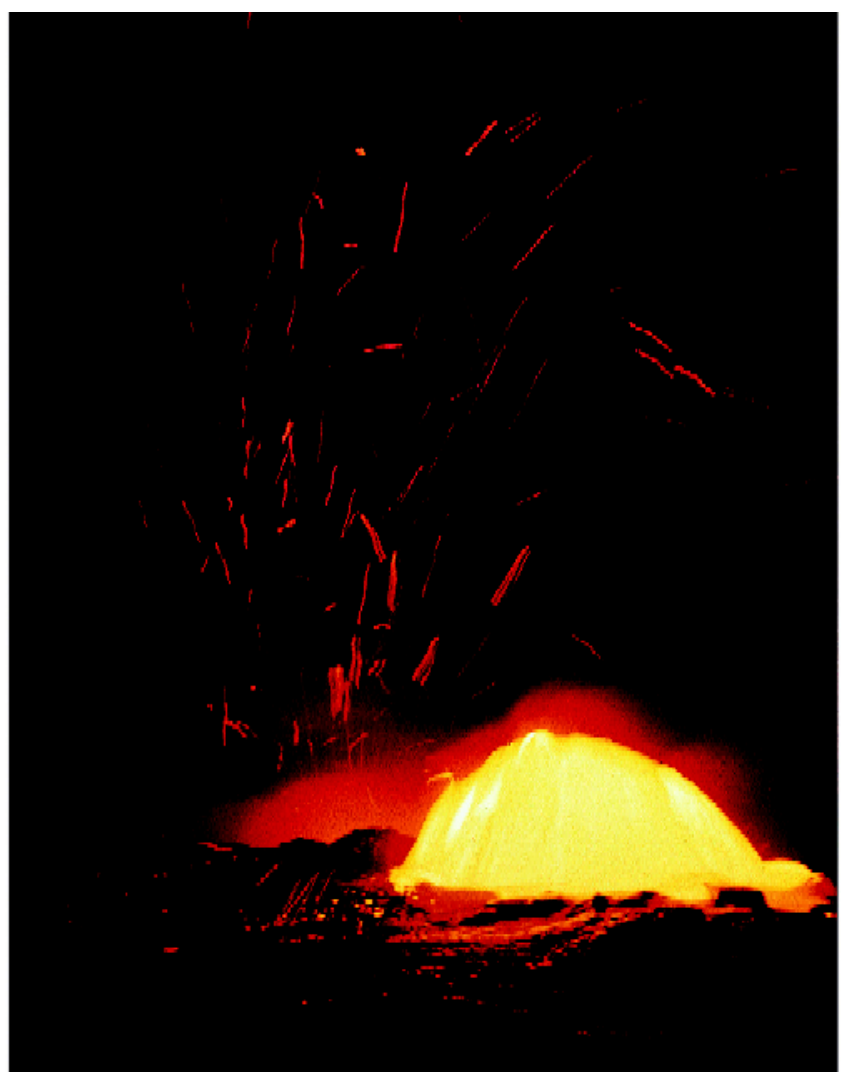

Fig. 8

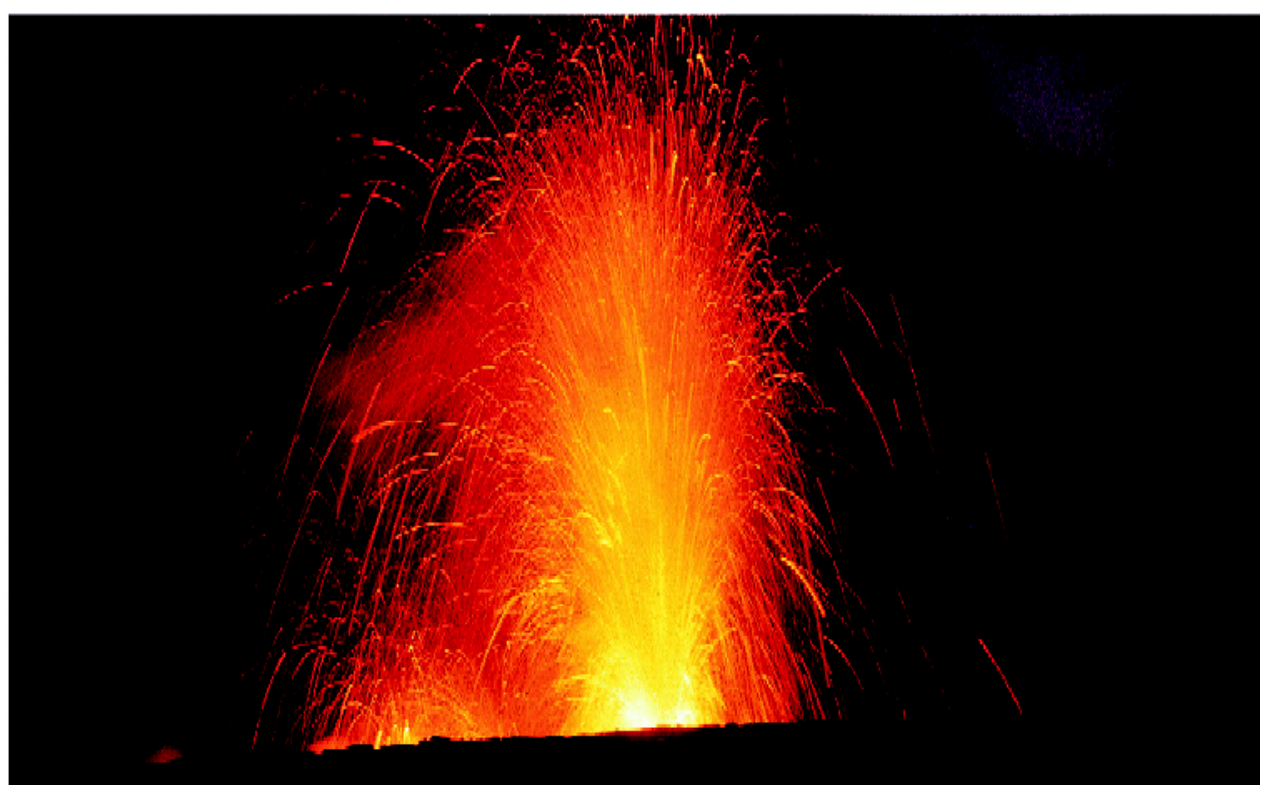

Fig. 10 


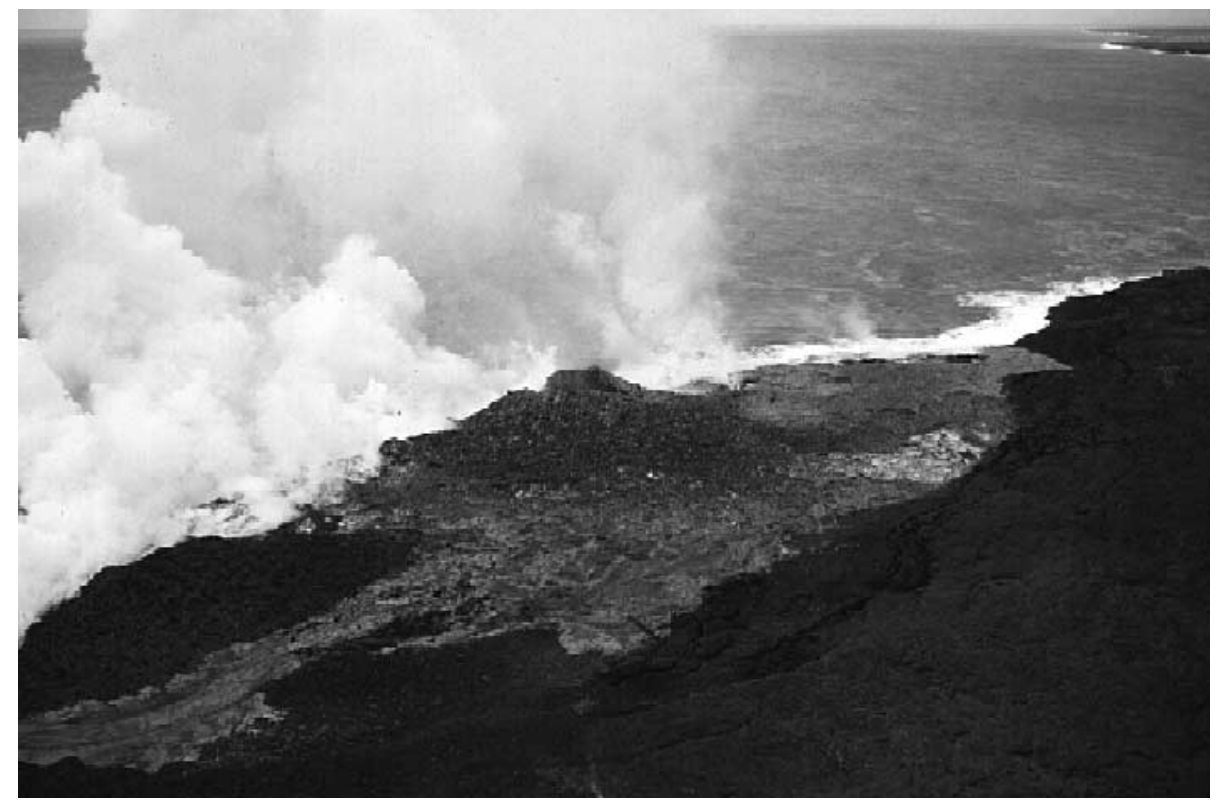

Fig. 9. Lava bench with two spatter-dominated littoral cones. The active lava bench is distinguishable from the main delta by a scarp that can be seen separating the light and the dark grey flows in the image. Explosive activity, following subsidence, built the cones. The circular cone in the middle of the photograph was built by bubble-burst activity in March 1994.

spatter-dominated, agglutinated circular cones or low mounds. The largest cone formed was $28 \mathrm{~m}$ in diameter along its base and rose $8 \mathrm{~m}$ above the bench surface (Fig. 9). The conduit within the cone was $\geq 10 \mathrm{~m}$ deep, and the underlying tube was below sea level.

\subsection{Littoral lava fountains}

Occasionally, abrupt fracturing of a submerged lava tube produces spectacular littoral lava fountains similar, although smaller, to the "continuous uprush" explosions viewed during the 1964-1965 eruption of Surtsey (Moore, 1985). This relatively rare type of explosion produces continuous fountains of molten lava and steam that reach heights of $\geq 100 \mathrm{~m}$ (Fig. 10). Fountains last between 10 and 45 minutes and are often preceded by bubble bursts. Both types of explosions can take place simultaneously, with the fountains emanating from a point deeper in the bench and closer to the shoreline (Fig. 4C). Timed clast trajectories indicate average ejection velocities of $25-45 \mathrm{~m} / \mathrm{s}$. In contrast to bubble-burst activity, fountaining events end with high-pressure jetting of steam.

Littoral lava fountains produce molten spatter bombs and lapilli, with lesser amounts of limu-o-Pele, Pele's hair, and ash. The surfaces of spatter bombs are commonly bread-crusted, altered, and peppered with annealed particles of palagonitized ash. Samples with palagonitized ash were collected within 24 hours of deposition. The ash fragments are mostly subrounded, equant to elongate in form, and are often clumped together with finer particles adhered to them (Fig. 11). Some of these particles are hollow spheres, others have attenuated (spindle or barbell)

Fig. 8. Bubble burst during explosive event on the Kamoamoa delta. Bubble is incandescent and about $0.5 \mathrm{~m}$ high. Omjalla Images photo by G.B. Lewis.

Fig. 10. A 100-m-high littoral lava fountain. Confined mixing of lava and seawater leads to these very dramatic and rare hydrovolcanic explosions. Photo by S.R. Mattox. 


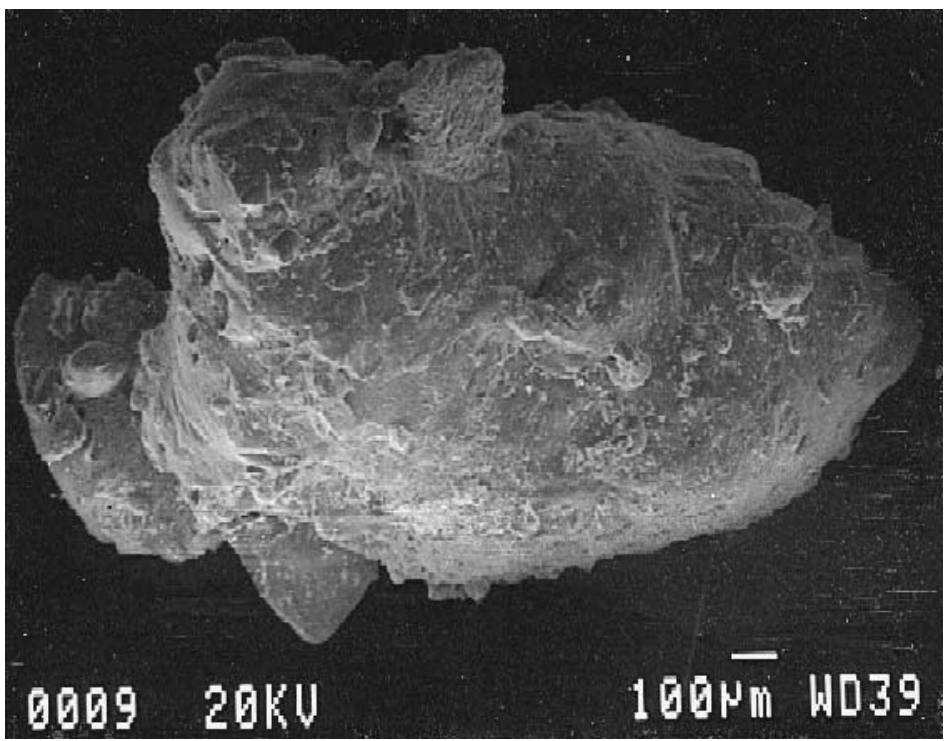

Fig. 11. SEM image of ash produced in littoral lava fountains.

or rounded shapes, and many are flat shards that appear to be broken fragments of limu-o-Pele. That no accretionary lapilli were found despite the copious amounts of steam produced during fountaining events probably reflects the overall scarcity of fines. In contrast to ash from tephra jet activity, the ash fraction from littoral lava fountains appears to be primary (i.e., molten break-up) and not the result of post-explosive mechanical fragmentation (Figs. 6 and 11). Fountaining events produce welded, circular spatter cones inland from the shoreline, similar to those formed during bubble-burst activity. The cones, however, form more rapidly. In one instance, a 7.5-m-high littoral cone formed in less than $20 \mathrm{~min}$ utes. Ash fragments were blown out to sea by high winds during the two observed littoral lava fountain events, and lava flows quickly covered any small deposits that may have blanketed the bench.

\section{Explosion mechanisms}

The explosive lava/seawater interactions described above are the result of rapid steam generation and explosive decompression. The phenomenon, known as a vapor explosion, or fuel-coolant inter- action, has been the subject of considerable investigation by engineers because of recurring industrial accidents involving spills of molten metals, liquefied natural gas, and paper smelts into water or other liquid coolants (e.g., Witte et al., 1970; Witte and Cox, 1978). That these industrial interactions provide useful analogs for hydrovolcanic activity has long been recognized (e.g., Colgate and Sigurgeirsson, 1973; Peckover et al., 1973; Sheridan and Wohletz, 1983; Wohletz, 1983).

Industrial vapor explosions occur when liquids of differing temperatures are brought into sudden contact, providing the temperature of the hotter liquid (the fuel) is significantly higher than the boiling point of the cooler liquid (the coolant). Within micro- to milliseconds, a dynamic process of fuel fragmentation, violent vapor generation, and explosive decompression is initiated. The exact mechanisms are elusive because of the difficulties inherent in experimentation, but there is a general consensus that the rate and degree of mixing are the controlling parameters (see discussions in Cronenberg, 1980; Corradini et al., 1989). Most models propose an explosive scenario that includes: (1) preliminary mechanically induced coarse mixing of fuel and coolant (premixing); (2) the formation of a vapor film at the 
fuel-coolant interface; (3) destabilization of the film, leading to direct contact between the two liquids; and (4) fine-scale fragmentation of the fuel and explosive vaporization of the coolant. Theoretical and experimental studies have shown that fine-scale fragmentation is required to produce the interactive surface area necessary to reconcile the observed energy release with known heat transfer rates (Board et al., 1974; Fröhlich et al., 1976; Fröhlich, 1987; Zimanowski et al., 1991; Fodemski, 1992). Although the factors governing fragmentation are yet to be resolved, existing models rely on either a homogeneous boiling or thermal detonation mechanism (see overviews in Cronenberg, 1980; Wohletz, 1986). Regardless of the responsible mechanism, $\mathrm{Zi}$ manowski et al. (1995) found in experimental simulations that silicate melts require a small external "trigger" of about $8 \mathrm{~J}$ to initiate this critical step in the explosive sequence.

In the context of our observations, vapor explosions are restricted to very specific conditions. First, a relatively high-volume $\left(\sim 4 \mathrm{~m}^{3} / \mathrm{s}\right)$, focused, lava entry is required. A diffuse flow front of numerous, minor streams, as occurs in the early stages of delta formation, is not conducive to explosive activity. Second, the association of explosive events with collapse or sloughing off of all or part of a bench indicates that contact between seawater and lava must be established abruptly, over time scales of a few seconds or less. In this dynamic setting, turbulent "premixing" of lava and water is expected. Unfortunately, field observations and measurements can give little insight into the succession of microscale events that follow premixing. Note, however, that the inferred contact temperature is well above the boiling point of seawater, and probably above the limit of superheating as well. The initial temperature at the clast-seawater interface $\left(T_{\mathrm{i}}\right)$ can be calculated from:

$T_{\mathrm{i}}=\frac{T_{\mathrm{m}}[\kappa / \sqrt{\alpha}]_{\mathrm{m}}+T_{\mathrm{w}}[\kappa / \sqrt{\alpha}]_{\mathrm{w}}}{[\kappa / \sqrt{\alpha}]_{\mathrm{m}}+[\kappa / \sqrt{\alpha}]_{\mathrm{w}}}$

where $T_{\mathrm{i}}$ is the interface temperature, $\kappa$ is thermal conductivity, and $\alpha$ is thermal diffusivity (Cronenberg, 1980). The subscripts $m$ and $w$ indicate parameters specific to melt and seawater, respectively. We find an interface temperature of $536-550^{\circ} \mathrm{C}$ using
$T_{\mathrm{m}}=1150^{\circ} \mathrm{C}\left(\right.$ Cashman and Mangan, 1994), $T_{\mathrm{w}}=$ $25-50^{\circ} \mathrm{C}$ (Tribble, 1991), $[\kappa / \sqrt{\alpha}]_{\mathrm{m}}=0.030$ cal s${ }^{-1 / 2} \mathrm{~cm}^{-2}{ }^{\circ} \mathrm{C}^{-1}$, and $[\kappa / \sqrt{\alpha}]_{w}=0.036$ $\mathrm{cal} \mathrm{s}^{-1 / 2} \mathrm{~cm}^{-2}{ }^{\circ} \mathrm{C}^{-1}$. The superheat limit for seawater as estimated from experimental data is substantially lower, $\sim 447^{\circ} \mathrm{C}$ [Wohletz (1986) after Sourirajan and Kennedy (1962)].

Given the above unifying characteristics, the various types of explosions may be classified according to one of the following mixing regimes: wave-induced "open mixing" at the surface (tephra jets, lithic blasts), or "confined mixing" in submerged lava tubes (littoral lava fountains, bubble bursts). Both regimes are discussed below.

\subsection{Open mixing}

The open mixing processes leading to tephra jets and lithic blast events commence when a bench collapse exposes an active lava tube or incandescent rock scarp to wave action. In this context, the term "mixing" refers to an abrupt increase in the interactive surface area and is not limited to the relative penetration of two liquids. In the most common situation, that of a severed lava tube, the impacting wave disrupts the stream of melt exiting the tube. This forced, coarse mixing appears to be a required element in the explosive sequence. In general, we found that the more intense the wave action (and hence the higher the impingement velocity), the more energetic the explosion.

Disruption by wave action increases the interactive surface area of the melt by more than an order of magnitude, from $\sim 20$ to $800 \mathrm{~m}^{2}$. For this calculation, we assume the dispersal of an originally cylindrical melt volume of $4 \mathrm{~m}^{3}$ into $0.03-\mathrm{m}$ diameter spherical clots (largest quenched clasts deposited). We estimate a water/melt mass mixing ratio of $\sim 0.15$, which is within the range of experimentally and theoretically determined ratios for hydrovolcanic explosions (Sheridan and Wohletz, 1983; Zimanowski et al., 1991). Our estimate is derived using a typical lava flux of $4 \mathrm{~m}^{3} / \mathrm{s}$, a wave impact duration of $1 \mathrm{~s}$, vesiculated $(20 \%)$ melt and seawater densities of 2160 and $1000 \mathrm{~kg} / \mathrm{m}^{3}$, respectively, a tube diameter of $1 \mathrm{~m}$ and an interactive wave volume of $1.3 \mathrm{~m}^{3}$ calculated from a parabolic volume section $1 \mathrm{~m}$ high, $1 \mathrm{~m}$ wide and $2 \mathrm{~m}$ deep. During the 
explosion, approximately $0.1 \mathrm{~kJ}$ of kinetic energy $(E)$ is released per kilogram of lava ejected, given that:

$V_{\max }=\sqrt{2(E)}$

(e.g., Mastin, 1995), where $V_{\max }$ is the maximum clast velocity $(15 \mathrm{~m} / \mathrm{s})$. This must be considered a minimum estimate, since our measured clast velocities are time averaged, and we have no data for the most energetic period immediately following the collapse of the bench.

Lithic blasts are a comparatively rare form of open mixing in which seawater comes into contact with hot, but solidified, lava. The minimum rock temperature required for explosive interaction can be estimated from Eq. (1). In order to attain an interface temperature greater than the boiling point of seawater, the rock must be at a temperature between 160 and $190^{\circ} \mathrm{C}$. The upper limit of interaction is given by the solidus of Kilauea basalt which, from lava lake studies, is known to be $\sim 980^{\circ} \mathrm{C}$ (Wright and Okamura, 1977). This corresponds to a maximum interface temperature of $375^{\circ} \mathrm{C}$. Ballistic analysis of the largest blast (04/19/93 event in Table 1) indicates ejection velocities up to $50 \mathrm{~m} / \mathrm{s}$ (method of Mastin, 1991). This suggests a kinetic energy release of 1.3 $\mathrm{kJ} / \mathrm{kg}$ of rock ejected (Eq. (2)), approximately $0.11 \%$ if the initial thermal energy of lava per $\mathrm{kg}$ (Wohletz et al., 1995). This is a minimum value for energy release since kinetic energy is required for fragmentation, excavation, and other unmeasured processes (Wohletz et al., 1995). These values are at the low end for hydrovolcanism (Wohletz et al., 1995); with higher water/melt ratios they would increase rapidly.

\subsection{Confined mixing}

Littoral lava fountains and bubble bursts occur when a lava tube situated at, or below, sea level fractures and seawater rushes into the system. For an explosion to occur, the vaporization pressure must nominally exceed the confining pressure derived from the weight of the overlying melt and rock. Near the margin of the bench, a maximum confining pressure between 0.14 and $0.25 \mathrm{MPa}$ is expected, assuming a 1-m-thick layer of melt overlain by 1-6 m of rock (J. Kauahikaua, USGS, unpublished geophysical data) and a melt and rock density of 2160 (Cashman and Mangan, 1994) and 2300 (Kinoshita et al., 1963) $\mathrm{kg} / \mathrm{m}^{3}$, respectively. Once the initial explosion has excavated the rock overlying the tube, the confining pressure drops to $0.12 \mathrm{MPa}$.

During the least energetic events (lava bubble bursts), the vaporization pulse lifts the overlying melt layer coherently as an expanding cupola, which eventually grows to the point of rupture. The explosive pressure must be at least as high as that of the confining pressure, and a minimum energy release of $\geq 0.07-0.35 \mathrm{~kJ} / \mathrm{kg}$ is expected. These values are based on estimates of the pressure-volume work done by the system;

$E=P \Delta V$

where $P(=0.12 \mathrm{MPa})$ is the confining pressure which must be overcome and $\Delta V\left(=0.9\right.$ to $\left.4.8 \mathrm{~m}^{3}\right)$ is the volume change associated with vaporization, which is calculated from the dimensions of the lava bubble as it emerges from the orifice (1-m diameter and $0.3-\mathrm{m}$-high dome) and from the excavated voidspace in the surface flows above the tube (1-m diameter and 1-6-m-high cylinder). Explosions of higher intensity (littoral lava fountains) disrupt the overlying melt layer, and melt fragments are entrained in the rising jet of steam and ash. Clast motions are ballistic, and time-averaged ejection velocities within the fountain $(45 \mathrm{~m} / \mathrm{s})$ suggest a substantially higher energy release of $\geq 1 \mathrm{~kJ} / \mathrm{kg}$ (Eq. (2)).

We speculate that it is the rate of seawater influx that governs the intensity of the explosion by controlling the water/melt ratio. Bubble burst activity appears to be the result of lower, unsteady infiltration rates. The explosions are sporadic, relatively little steam is emitted during the burst and, at the end of the burst, lava pools in the conduit indicating that the supply of water has run out. In contrast, the continuous nature of fountaining events suggests a steady, accessible source of water. The steam jets that mark the end of a fountaining episode imply a depletion of melt rather than water at the explosion site. These inferences are consistent with our observation that, relative to bubble bursts, littoral lava fountains emanate from points deeper in the bench and closer to the shoreline, where seawater influx is likely to be greater (Fig. 4C). Explosion sources are 
below sea level, in agreement with a configuration proposed by Moore (1985) to explain the nature of the "continuous-uprush" explosions observed at Surtsey.

\section{Summary and discussion}

The factors leading to littoral hydrovolcanic explosions involving pahoehoe flows include a relatively high volume focused lava entry $\left(\sim 4 \mathrm{~m}^{3} / \mathrm{s}\right.$ flow through a $1-\mathrm{m}$ diameter tube) and full or partial collapse of an active lava bench. The abrupt increase in interactive surface area (premixing) initiated by a collapse results in rapid generation of steam (335$550^{\circ} \mathrm{C}$ interface temperature) and explosive decompression (0.07-1.3 kJ/kg energy release). Water/melt ratios estimated from field measurements ( $\geq 0.15$ ) fall within experimentally derived values for hydrovolcanic activity. The types of explosions observed fall into two mixing regimes: "open mixing" induced by wave action and "confined mixing" in submerged lava tubes. Tephra jets and lithic blasts are examples of open mixing of ocean waves and an incandescent fault scarp or lava from a severed lava tube. Bubble bursts and littoral lava fountains are the result of confined mixing due to seawater infiltration of a submerged lava tube. In relative terms, the explosive intensity of lithic blasts $>$ littoral lava fountains $\geq$ tephra jets $\gg$ bubble bursts. The ash found in tephra jet deposits appears to have evolved via post-explosion mechanical fragmentation of larger delicate glass fragments such as Pele's hair and limu-o-Pele. In contrast, the finer fragments in littoral lava fountains appear to be primary, consistent with greater fragmentation and, thus, higher explosive energies. In general, we find that the proportion of non-interactive (entrained) melt is highest under confined mixing conditions.

Characteristic landforms and deposits are associated with the four types of hydrovolcanic explosions. Unconsolidated, semi-circular littoral cones and deposits of quenched angular fragments are evidence for unconfined mixing following the collapse of an unstable, active bench. Deposits of angular blocks of lava are clear evidence of a complete bench collapse and an ensuing lithic blast; however, care should be taken not to confuse these deposits with deposits emplaced by high waves and storm surf. Welded circular spatter mounds and littoral cones and deposits of spatter and attenuated tephra particles are the result of confined mixing of water and melt in a lava tube.

Interestingly, historic littoral cones in Hawai ' $i$ are generally associated with 'a'a, rather than pahoehoe, flows, and are significantly larger than the cones we describe here. Pre-erosional heights of 20 to more than $90 \mathrm{~m}$ are not uncommon (Moore and Ault, 1965). 'A'a-related cones appear to have a much larger percentage of unconsolidated ash and lapillisized fragments (Moore and Ault, 1965; Fisher, 1968), suggesting higher explosive energies. Entry fluxes estimated for these older cone-forming flows (Moore and Ault, 1965) are one to two orders of magnitude greater than the tube fluxes determined for the current Kilauea eruption. In light of our observations, it is likely that the more energetic interactions inferred for the seaward incursion of ' $a$ ' $a$ flows are a direct result of higher lava flux. The clinkery character of ' $a$ 'a flows may also induce more efficient premixing and, hence, greater explosivity. While failure of a lava delta appears to be a necessary trigger for littoral explosions involving pahoehoe flows, it may not be a necessary prerequisite for ' $a$ ' a flows. Higher lava flux rates and a fragmented flow morphology may eliminate this requirement.

Based on the morphology of historic cones and their source flows ('a'a flows with open channels and not tube-fed pahoehoe), historic littoral cones may have been formed by tephra jets. A cursory comparison of individual ash fragments from two historic cones, $\mathrm{Pu}$ 'u Hou and Sand Hill (Heiken and Wohletz, 1992, pp. 127-128), and those produced in tephra jets shows that they are morphologically similar. This supports the speculation that tephra in historic littoral cones was produced by tephra jets, the result of an extremely high and focused volume flux into the ocean, followed by turbulent unconfined mixing of lava and ocean water.

\section{Acknowledgements}

We appreciate reviews by Ken Wohletz, Lionel Wilson, Larry Mastin, Jim Moore, Jane Takahashi 
and Dave Clague. Their comments were extremely helpful. This manuscript benefited from early discussions with, and insights provided by, Dave Clague, Roger Denlinger, Christina Heliker, Ken Hon, Jim Kauahikaua, and Steve Mattox. Jim Kauahikaua compiled Fig. 1 from HVO GIS data. We are grateful to our team of students and volunteers, in particular, Tim Orr, Beth Rinard, Andrea Kaawaloa, and Matt Kulow for their help in the field and in the office.

\section{References}

Board, S.J., Farmer, C.L. and Poole, D.H., 1974. Fragmentation in thermal explosions. Int. J. Heat Mass Trans., 17: 31-339.

Cashman, K.V. and Mangan, M.T., 1994. Physical aspects of magmatic degassing, II. Constraints on vesiculation processes from textural studies of eruptive products. In: M.R. Carroll and J.R. Holloway (Editors), Rev. Mineral., 30: 447-478.

Colgate, S.A. and Sigurgeirsson, T., 1973. Dynamic mixing of water and lava. Nature, 244: 552-555.

Corradini, M., Bang, K.Y. and Tang, J., 1989. Fuel-coolant interactions and vapor explosions. Proc. U.S. Nucl. Reg. Comm. NUREG/CP-0105, 2: 223-247.

Cronenberg, A.W., 1980. Recent developments in the understanding of energetic molten fuel-coolant interactions. Nucl. Saf., 21(3): 319-337.

Fisher, R.V., 1968. Puu Hou littoral cones, Hawaii. Geol. Rundsch., 57(3): 837-864.

Fodemski, T.R., 1992. Forced convection film boiling in the stagnation region of a molten drop and its application to vapor explosions. Int. J. Heat Mass Trans., 35(8): 2005-2016.

Fröhlich, G., 1987. Interaction experiments between water and hot melts in entrapment and stratification configurations. Chem. Geol., 62: 137-147.

Fröhlich, G., Muller, G. and Unger, H., 1976. Experiments with water and hot melts of lead. J. Non-Equil. Thermodyn., 1: 91-103.

Heiken, G. and Wohletz, K., 1992. Volcanic Ash. Univ. California Press, Berkeley, CA, 246 pp.

Heliker, C.C., Mattox, T.N., Mangan, M.T. and Kauahikaua, J., 1993. Kilauea Volcano update: eleven-year-long eruption continues. Eos, Trans. Am. Geophys. Union Suppl., 74(43): 644.

Hon, K., Heliker, C.C. and Kjargaard, J.I., 1988. Limu o Pele: a new kind of hydroclastic tephra from Kilauea Volcano, Hawaii. Geol. Soc. Am., Abstr. Progr., 20(7): A112-A113.

Hon, K., Mattox, T., Kauahikaua, J. and Kjargaard, J., 1993. The construction of pahoehoe lava deltas on Kilauea Volcano, Hawaii. Eos, Trans. Am. Geophys. Union Suppl., 74(43): 616.

Jackson, D.B., Kauahikaua, J.P., Hon, K. and Heliker, C.C., 1988. Rate and variation of magma supply to the active lava lake on the middle east rift zone of Kilauea Volcano, Hawaii. Geol. Soc. Am., Abstr. Progr., 20(7): A397.
Kauahikaua, J., Denlinger, R., Foster, J. and Keszthelyi, L., 1993. Lava delta instability: Is it mass-wasting or is it triggered by lava flowing through tubes? Eos, Trans. Am. Geophys. Union Suppl., 74(43): 616.

Kauahikaua, J., Mangan, M., Heliker, C. and Mattox, T., 1996. A quantitative look at the demise of a basaltic vent - The death of Kupaianaha, Kilauea Volcano, Hawai'i. Bull. Volcanol., 57: 641-648.

Kinoshita, W.T., Krivoy, H.L., Mabey, D.R. and MacDonald, R.R., 1963. Gravity survey of the island of Hawaii. U.S. Geol. Surv., Prof. Pap., 475-C: C114-C116.

Mastin, L.G., 1991. The roles of magma and groundwater in the phreatic eruptions at Inyo Craters, Long Valley Caldera, California. Bull. Volcanol., 53: 579-596.

Mastin, L.G., 1995. Thermodynamics of gas and steam-blast eruptions. Bull. Volcanol., 57: 85-98.

Mattox, T.N., 1993a. Hydrovolcanic explosive activity where lava meets the sea, Kilauea Volcano, Hawai'i. Eos, Trans. Am. Geophys. Union Suppl., 74(43): 616-617.

Mattox, T.N., 1993b. Where lava meets the sea: Kilauea Volcano, Hawai'i. Earthquake Volcanol., 24(4): 160-177.

Moore, J.G., 1985. Structure and eruptive mechanisms at Surtsey Volcano, Iceland. Geol. Mag., 122: 649-661.

Moore, J.G. and Ault, W.U., 1965. Historic littoral cones in Hawaii. Pac. Sci., XIX(1): 3-11.

Moore, J.G., Phillips, R.L., Grigg, R.W., Peterson, D.W. and Swanson, D.A., 1973. Flow of lava into the sea, 1969-1971, Kilauea Volcano, Hawaii. Geol. Soc. Am. Bull., 84(2): 537546.

Peckover, R.S., Buchanan, D.J. and Ashby, D.E.T.F., 1973. Fuel-coolant interactions in submarine vulcanism. Nature, 245: $307-308$.

Sansone, F.J., Resing, J.A., Tribble, G.W., Sedwick, P.N., Kelly, K.M. and Hon, K., 1991. Lava-seawater interactions at shallow-water submarine lava flows. Geophys. Res. Lett., 18(9): 1731-1734.

Sheridan, M.F. and Wohletz, K.H., 1983. Hydrovolcanism: basic considerations and review. J. Volcanol. Geotherm. Res., 17: $1-29$.

Sourirajan, S. and Kennedy, G.C., 1962. The system $\mathrm{H}_{2} \mathrm{O}-\mathrm{NaCl}$ at elevated temperatures and pressures. Am. J. Sci., 260: $115-141$

Tribble, G.W., 1991. Underwater observations of active lava flows from Kilauea Volcano, Hawaii. Geology, 19(6): 633636.

Witte, L.C. and Cox, J.E., 1978. The vapor explosion — a second look. J. Metals, 30(10): 29-35.

Witte, L.C., Cox, J.E. and Bouvier, J.E., 1970. The vapor explosion. J. Metals, 22(2): 39-44.

Wohletz, K.H., 1983. Mechanisms of hydrovolcanic pyroclast formation: grain-size, scanning electron microscopy, and experimental studies. J. Volcanol. Geotherm. Res., 17: 31-63.

Wohletz, K.H., 1986. Explosive magma-water interactions: thermodynamics, explosion mechanisms, and field studies. Bull. Volcanol., 48: 245-264.

Wohletz, K., McQueen, R. and Morrissey, M., 1995. Experimen- 
tal study of hydrovolcanism by fuel-coolant interaction analogs. Proc. Joint NSF/JSPS AMIGO-IMI Seminar, Santa Barbara, CA, June 8-13, 1995, 31 pp. (in press).

Wright, T.L. and Okamura, R.T., 1977. Cooling and crystallization of tholeiitic basalt, 1965 Makaopuhi lava lake, Hawaii. U.S. Geol. Surv., Prof. Pap. 1004, 78 pp.
Zimanowski, B., Fröhlich, G. and Lorenz, V., 1991. Quantitative experiments on phreatomagmatic explosions. J. Volcanol. Geotherm. Res., 48: 341-358.

Zimanowski, B., Fröhlich, G. and Lorenz, V., 1995. Experiments on steam explosion by interaction of water with silicate melts. Nucl. Eng. Des., 155: 335-343. 